\title{
PENGARUH JUMLAH SIMPANAN, JUMLAH KREDIT, DAN JUMLAH MODAL KERJA TERHADAP JUMLAH SISA HASIL USAHA (SHU) PADA KOPERASI SIMPAN PINJAM YANG BERNAUNG DI BAWAH DINAS KOPERASI DAN UMKM KOTA DENPASAR TAHUN 2018-2019
}

\author{
al Made Suidarma, ' Dewa Nyoman Marsudiana, buh Bonita Paramadewi \\ Universitas Pendidikan Nasional (UNDIKNAS) Denpasar \\ suidarma@undiknas.ac.id
}

\begin{abstract}
The purpose of this study was to determine the effect of Amount of Savings, Amount of Credit, and Amount of Working Capital on Amount of Remaining Business Results in Savings and Loans Cooperatives Under the Office of Cooperatives and UMKM of Denpasar City in 2018-2019. The population in this study amounted to 45 savings and loan cooperatives. The sampling technique used in this study was purposive sampling with a total of 24 savings and loan cooperatives on the condition that they submit the Annual Member Meeting report. By using the $T$ test and $F$ test, the results of this study partially the amount of savings on the amount of residual income has an effect, the amount of credit on the amount of residual income has an effect, and the amount of working capital on the amount of residual income has an effect. However, simultaneously all independent variables have a significant effect on the amount of Remaining Operating Results.
\end{abstract}

Keywords : Savings, Credit, Working Capital, and Remaining Business Results.

\begin{abstract}
ABSTRAK
Tujuan penelitian ini adalah untuk mengetahui pengaruh Jumlah Simpanan, Jumlah Kredit, dan Jumlah Modal Kerja terhadap Jumlah Sisa Hasil Usaha (SHU) pada Koperasi Simpan Pinjam yang Bernaung di Bawah Dinas Koperasi dan UMKM Kota Denpasar tahun 2018-2019. Adapun populasi dalam penelitian ini berjumlah 45 koperasi simpan pinjam. Teknik pengambilan sampel yang digunakan dalam penelitian ini adalah purposive sampling dengan jumlah 24 koperasi simpan pinjam dengan syarat menyerahkan laporan Rapat Anggota Tahunan (RAT). Dengan menggunakan uji $T$ dan uji $F$, hasil penelitian ini secara parsial jumlah simpanan terhadap jumlah sisa hasil usaha berpengaruh, jumlah kredit terhadap jumlah sisa hasil usaha berpengaruh, dan jumlah modal kerja terhadap jumlah sisa hasil usaha berpengaruh. Namun secara simultan semua variabel independen berpengaruh signifikan terhadap jumlah Sisa Hasil Usaha (SHU).
\end{abstract}

Kata Kunci : Simpanan, Kredit, Modal Kerja, dan Sisa Hasil Usaha (SHU).

\section{INTRODUCTION}

Perekonomian di Indonesia yang berdasarkan pada demokrasi ekonomi dimana masyarakat harus berperan aktif dalam pembangunan perekonomian. Oleh sebab itu pemerintah sangat mendorong pertumbuhan ekonomi dengan menetapkan berbagai kebijaksanaan guna menciptakan iklim usaha yang baik bagi dunia usaha. Untuk mencapai tujuan, koperasi diharapkan dapat memegang peranan penting karenai salah satu tulang punggung perekonomian Indonesia.

Pengelolaan koperasi yang baik apabila setiap tahunnya diperoleh yang dapat dipertanggungjawabkan kepada para anggota. Namun koperasi yang mempunyai asset dan 
volume perdagangan usaha yang besar di Indonesia masih sedikit. Hal ini terjadi karena berbagai kendala: 1) Masalah dari segi simpanan. Terbatasnya modal dalam koperasi menyebabkan sulitnya mengembangkan unit-unit usaha yang diharapkan dapat meningkatkan kesejahteraan anggota. 2) Masalah pemberian kredit. Kredit yang diberikan terbatas sesuai dengan modal yang dimiliki. Selain itu, apabila yang dimiliki tidak dimanfaatkan dengan baik maka dapat menghambat peningkatan SHU dan 3) Kurang baiknya modal kerja. Modal kerja merupakan modal yang digunakan dan berputar dalam operasional koperasi perputaran modal akan menghasilkan keuntungan bagi koperasi. Apabila tidak baiknya modal kerja akan berakibat menurunnya keuntungan yang dihasilkan koperasi.

Tabel 1. Data Jumlah Koperasi, Jumlah Modal, dan Jumlah Sisa Hasil Usaha (SHU) pada Dinas Koperasi Usaha Kecil dan Menengah Pemerintahan Kota Denpasar Tahun 2017-2018

\begin{tabular}{|c|c|c|c|}
\hline No. & Uraian & $\begin{array}{c}\text { Per } 31 \text { Desember } \\
2018\end{array}$ & $\begin{array}{c}\text { Per } 31 \text { Desember } \\
2019\end{array}$ \\
\hline 1. & $\begin{array}{l}\text { Jumlah Koperasi } \\
\text { yang Dikunjungi } \\
\text { a. Koperasi Simpan } \\
\text { Pinjam } \\
\text { b. Koperasi Serba } \\
\text { Usaha }\end{array}$ & $\begin{array}{l}45 \text { unit } \\
46 \text { unit }\end{array}$ & $\begin{array}{l}45 \text { unit } \\
46 \text { unit }\end{array}$ \\
\hline 2. & $\begin{array}{l}\text { Jumlah Modal } \\
\text { a. Modal Sendiri } \\
\text { b. Modal Luar }\end{array}$ & $\begin{array}{r}\text { Rp 449.421.143.307 } \\
\text { Rp 1.484.727.773.828 }\end{array}$ & $\begin{array}{r}\text { Rp 486.549.142.189 } \\
\operatorname{Rp} 1.612 .097 .436 .823\end{array}$ \\
\hline 3. & Jumlah SHU & Rp 90.356.094.273 & Rp 92.163.216.158 \\
\hline
\end{tabular}

Berdasarkan tabel 1, jumlah koperasi yang dikunjungi Dinas Koperasi dan UMKM Kota Denpasar pada tahun 2017-2018 yaitu 91 unit koperasi. Jumlah modal koperasi pada tahun 2018 berjumlah $\mathrm{Rp} 1.934 .148 .917 .135$ dan pada tahun 2019 berjumlah $\mathrm{Rp} 2.098 .646 .579 .012$ sehingga jumlah modal kerja mengalami peningkatan sebesar $R p$ 164.497.661.877. Dan jumlah sisa hasil usaha koperasi mengalami peningkatan sebesar Rp 1.807.121.885.

Sehingga sesuai latar belakang yang telah diuraikan, maka peneliti ingin melakukan penelitian dengan judul: "Pengaruh Jumlah Simpanan, Jumlah Kredit, dan Jumlah Modal Kerja Terhadap Jumlah Sisa Hasil Usaha (SHU) pada Koperasi Simpan Pinjam yang Bernaung Di Bawah Dinas Koperasi dan UMKM Kota Denpasar Tahun 2018-2019".

\section{LITERATURE REVIEW}

\section{Modal Koperasi}

Menurut Hendrojogi (2015), modal diartikan sebagai hasil produksi yang digunakan untuk memproduksi lebih lanjut. Dalam perkembangannya, pengertian modal mengarah kepada sifat non-physical, dalam arti modal ditekankan kepada nilai, daya beli atau kekuasaan memakai atau menggunakan yang terkandung dalam barang modal.

Dalam UU No. 12/1967 tentang Pokok-Pokok Perkoperasian Pasal 32 ayat (1) ditentukan bahwa modal koperasi terdiri dari dan dipupuk dari simpanan, pinjaman, penyisihan dari hasil usahanya termasuk cadangan serta sumber-sumber lain. Kemudian dalam ayat (2) dikatakan bahwa simpanan anggota di dalam koperasi terdiri dari: simpanan pokok, simpanan wajib, dan simpanan sukarela.

\section{Kredit}

Pengertian kredit pada Pasal 1 Ayat 11 Undang-Undang No. 10 Tahun 1998 tentang Perbankan adalah penyediaan uang atau tagihan yang dapat dipersamakan dengan itu, 
berdasarkan persetujuan atau kesepakatan pinjam-meminjam antar bank dengan pihak lain yang mewajibkan pihak peminjam untuk melunasi utangnya setelah jangka waktu tertentu dengan pemberian bunga.

\section{Modal Kerja}

Modal kerja adalah keseluruhan aktiva lancar yang dimiliki perusahaan, atau dapat pula dimaksudkan sebagai dana yang harus tersedia untuk membiayai kegiatan operasi perusahaan sehari-hari (Agnes Sawir, 2005). Pendapat lain menyatakan bahwa modal kerja (working capital) adalah selisih aktiva lancar setelah dikurangi kewajiban lancar (James C Horne dan John M. W. Jr, 2005).

\section{Sisa Hasil Usaha (SHU)}

Sisa hasil usaha merupakan laba bersih seperti lazimnya dalam dunia usaha yang dilaporkan pada akhir tiap periode. Menurut Amin Tunggal Wijaya (2002), "Sisa hasil usaha koperasi adalah pendapatan koperasi yang diperoleh dalam satu tahun, dikurangi dengan penyusutan dan biaya dari tahun buku yang bersangkutan atau biasa disebut dengan laba bersih".

\section{A. Hipotesis}

Penelitian terdahulu yang dilakukan oleh Muhammad Razali (2017) yang berjudul "Pengaruh Jumlah Anggota, Jumlah Simpanan, Jumlah Modal Kerja, dan Volume Usaha Terhadap Perolehan Sisa Hasil Usaha Pada Koperasi Se-Kota Tanjungpinang", yang menemukan hasil penelitian bahwa jumlah simpanan memiliki pengaruh positif signifikan terhadap Sisa Hasil Usaha (SHU).

$\mathrm{H}_{1} \quad$ : Jumlah simpanan berpengaruh positif signifikan terhadap jumlah sisa hasil usaha.

Penelitian terdahulu yang dilakukan oleh Firas Septian, Anjuman Zukhri, dan Made Ary Meitriana (2014) yang berjudul "Pengaruh Jumlah Kredit dan Jumlah Simpanan Terhadap Rentabilitas Pada KPRI Balidita Gondol Periode 2008-2012", menemukan hasil bahwa jumlah kredit memiliki pengaruh positif signifikan terhadap rentabilitas.

$\mathrm{H}_{2} \quad$ : Jumlah kredit berpengaruh positif signifikan terhadap jumlah sisa hasil usaha.

Penelitian terdahulu yang dilakukan oleh Muhammad Razali (2017) yang berjudul "Pengaruh Jumlah Anggota, Jumlah Simpanan, Jumlah Modal Kerja, dan Volume Usaha Terhadap Perolehan Sisa Hasil Usaha Pada Koperasi Se-Kota Tanjungpinang", yang menemukan hasil penelitian bahwa jumlah modal kerja memiliki pengaruh positif signifikan terhadap Sisa Hasil Usaha (SHU).

$\mathrm{H}_{3} \quad$ : Jumlah modal kerja berpengaruh positif signifikan terhadap jumlah sisa hasil usaha.

Penelitian terdahulu yang dilakukan oleh Muhammad Razali (2017) apabila simpanan, kredit, dan modal kerja suatu koperasi banyak maka dapat berpengaruh positif bagi perolehan SHU yang didapatkan oleh koperasi namun sebaliknya apabila simpanan, kredit, dan modal kerja koperasi sedikit maka dapat berpengaruh negatif terhadap perolehan SHU yang di dapatkan oleh koperasi.

$\mathrm{H}_{4} \quad$ : Jumlah simpanan, jumlah kredit, dan jumlah modal kerja secara bersama-sama mempunyai pengaruh secara signifikan terhadap jumlah sisa hasil usaha.

\section{B. Kerangka Pikir}

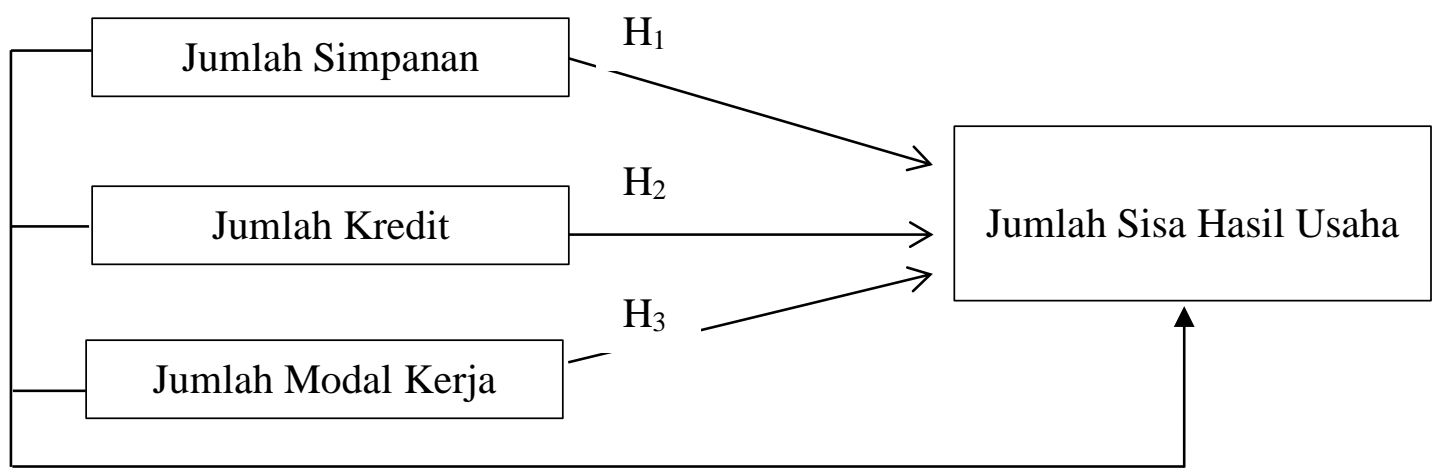




\section{Materials and Methods}

Penelitian ini menggunakan metode kuantitatif. Populasinya adalah Laporan Rapat Anggota Tahunan Koperasi Simpan Pinjam yang Bernaung Di Bawah Dinas Koperasi dan UMKM Kota Denpasar yang berjumlah 45 koperasi simpan pinjam.. Sampelnya adalah Koperasi Simpan Pinjam yang menyerahkan laporan RAT (Rapat Anggota Tahunan) ke Dinas Koperasi dan UMKM Kota Denpasar tahun 2018-2019 dan jumlah simpanan, kredit, modal kerja, dan sisa hasil usaha pada tahun 2018-2019 yang berjumlah 24 Koperasi Simpan Pinjam yang bernaung di bawah Dinas Koperasi dan UMKM Kota Denpasar.

Result and Discussion

Uji Normalitas

Tabel 1

Hasil Uji Normalitas

One Sample Kolmogorov Smirnov Test

\begin{tabular}{llr}
\multicolumn{1}{c}{} & \multicolumn{1}{c}{$\begin{array}{c}\text { Unstandardized } \\
\text { Residual }\end{array}$} \\
\hline $\mathrm{N}$ & & 48 \\
\hline Normal Parameters & Mean & .0000000 \\
\cline { 2 - 3 } & Std. Deviation & 162536768.2 \\
\hline \multirow{2}{*}{ Most Extreme Differences } & Absolute & .167 \\
\cline { 2 - 3 } & Positive & .167 \\
\cline { 2 - 3 } & Negative & -.104 \\
\hline Test Statistic & & 1.160 \\
\hline Asymp. Sig. (2-tailed) & & .135 \\
\hline
\end{tabular}

a. Test distribution is Normal.

Sumber : Hasil Pengolahan Data

Hasil di atas merupakan hasil uji normalitas yaitu hubungan jumlah simpanan, jumlah kredit, dan jumlah modal kerja terhadap jumlah sisa hasil usaha. Dari hasil di atas, dapat di lihat pada bagian Asymp. Sig. (2-tailed) berada di atas 0,05, hal ini menunjukkan bahwa data berdistribusi normal.

Uji Multikolinearitas

Tabel 2

Hasil Uji Multikolinearitas

Coefficients $^{\mathrm{a}}$

\begin{tabular}{|l|r|r|}
\hline \multirow{2}{*}{ Model } & \multicolumn{2}{|c|}{ Colinearity Statistics } \\
\cline { 2 - 3 } & \multicolumn{2}{|c|}{ Tolerance } \\
\hline (Constant) & & \multicolumn{1}{c|}{ VIF } \\
\hline Simpanan & 0,160 & 6,248 \\
\hline Kredit & 0,142 & 7,036 \\
\hline Modal Kerja & 0,652 & 1,534 \\
\hline
\end{tabular}

a. Dependent Variabel : Sisa Hasil Usaha

Sumber : Hasil Pengolahan Data

Hasil di atas menunjukkan bahwa variabel bebas memiliki nilai tolerance lebih besar dari 0,1 dan nilai VIF lebih kecil dari 10,00. Maka dari itu dapat disimpulkan bahwa tidak terdapat gejala multikolinearitas yang artinya baik.

\section{Uji Heteroskedastisitas}


Tabel 3

Hasil Uji Heteroskedastisitas

Correlations

\begin{tabular}{|c|c|c|c|}
\hline \multicolumn{2}{|c|}{ Model } & Spearman's Rho & $\begin{array}{c}\text { Unstandardized } \\
\text { Residual }\end{array}$ \\
\hline 1 & Simpanan & Sig. (2-tailed) & .714 \\
\hline 2 & Kredit & Sig. (2-tailed) & .301 \\
\hline 3 & Modal Kerja & Sig. (2-tailed) & .096 \\
\hline
\end{tabular}

a. Correlation is significant at the 0,01 level (2-tailed)

Sumber : Hasil Pengolahan Data

Berdasarkan hasil tabel di atas, menunjukkan bahwa model memiliki nilai unstandardized residual yaitu lebih besar dari 0,05 . Hal ini menunjukkan bahwa tidak terjadi heteroskedastisitas.

\section{Uji Autokorelasi}

Tabel 4

Hasil Uji Autokorelasi

Model Summary ${ }^{b}$

\begin{tabular}{|c|c|c|}
\hline \multicolumn{2}{|c|}{$\mathbf{k ( 3 )}$ dan N(48) } & Durbin-Watson \\
\hline dU & 4-dU & 1,961 \\
\hline 1,670 & 2,33 & \\
\hline
\end{tabular}

a. Predictors : (Constant), Modal Kerja, Simpanan, Kredit

b. Dependent Variable : Sisa Hasil Usaha

Sumber : Hasil Pengolahan Data

Berdasarkan hasil tabel di atas, menunjukkan bahwa nilai dU $<$ Durbin-Watson $<4$-dU yaitu $1,670<1,961<2,33$, maka model regresi tidak ada gejala autokorelasi.

Uji Analisis Regresi Linier Berganda

Tabel 5

Hasil Analisis Regresi Linier Berganda

Coeffcients $^{\mathrm{a}}$

\begin{tabular}{|c|c|c|c|c|c|c|}
\hline \multicolumn{2}{|c|}{ Model } & \multicolumn{2}{|c|}{$\begin{array}{c}\text { Unstandardized } \\
\text { Coeffcients }\end{array}$} & $\begin{array}{c}\text { Standardized } \\
\text { Coeffcients }\end{array}$ & \multirow{2}{*}{ T } & \multirow{2}{*}{ Sig } \\
\cline { 3 - 5 } \multicolumn{2}{|c|}{} & B & Std. Error & Beta & & \\
\hline \multirow{3}{*}{1} & (Constant) & -920 & 520 & & -1.733 & .090 \\
\cline { 2 - 7 } & Simpanan & -.064 & .021 & -.549 & -3.067 & .004 \\
\cline { 2 - 7 } & Kredit & .108 & .017 & 1.203 & 6.333 & .000 \\
\hline & Modal Kerja & .130 & .053 & .220 & 2.481 & .017 \\
\hline
\end{tabular}

a. Dependent Variable : Sisa Hasil Usaha

Sumber : Hasil Pengolahan Data

Hasil di atas berarti bahwa nilai signifikansi dari ketiga variabel bebas lebih kecil dari 0,05, yaitu seluruh variabel bebas berpengaruh signifikan terhadap $\mathrm{Y} 1$.

Uji Koefisien Determinasi $\left(\mathbf{R}^{2}\right)$

Tabel 6

Hasil Koefisien Determinasi $\left(R^{2}\right)$

Model Summary ${ }^{b}$

\begin{tabular}{|c|c|c|c|c|}
\hline Model & R & R Square & $\begin{array}{c}\text { Adjusted R } \\
\text { Square }\end{array}$ & $\begin{array}{c}\text { Std. Error of } \\
\text { the Estimate }\end{array}$ \\
\hline
\end{tabular}




\begin{tabular}{|c|c|c|c|c|}
\hline 1 & $.880^{\mathrm{a}}$ & .774 & .759 & 167 \\
\hline
\end{tabular}

a. Predictors : (Constant), Modal Kerja, Simpanan, Kredit

b. Dependent Variable : Sisa Hasil Usaha Sumber : Hasil Pengolahan Data

Nilai dari $R$ Square adalah sebesar 0,774 . Hal ini menunjukkan bahwa kontribusi pengaruh $\mathrm{X} 1, \mathrm{X} 2$, dan $\mathrm{X} 3$ terhadap $\mathrm{Y} 1$ adalah sebesar $77,4 \%$ sementara sisanya $22,6 \%$ merupakan kontribusi dari variabel lainnya di luar penelitian.

\section{Hypothesis Testing}

a) Pengaruh Jumlah Simpanan Terhadap Jumlah Sisa Hasil Usaha

Menurut hasil penelitian yang sudah didapat, menunjukkan bahwa nilai Sig. $=0,004(\alpha<$ 0,05 ) dan uji t sebesar $-3,067$, maka disimpulkan bahwa jumlah simpanan berpengaruh negatif signifikan terhadap jumlah sisa hasil usaha pada koperasi simpan pinjam yang bernaung di bawah Dinas Koperasi dan UMKM Kota Denpasar tahun 2018-2019 dan $\mathrm{H}_{1}$ yang menyatakan jumlah simpanan berpengaruh positif dan signifikan terhadap jumlah sisa hasil usaha ditolak.

b) Pengaruh Jumla Kredit Terhadap Jumlah Sisa Hasil Usaha

Menurut hasil penelitian yang sudah didapat, menunjukkan bahwa nilai Sig. $=0,000(\alpha<$ $0,05)$ dan uji t sebesar 6,333, maka disimpulkan bahwa jumlah kredit berpengaruh positif signifikan terhadap jumlah sisa hasil usaha pada koperasi simpan pinjam yang bernaung di bawah Dinas Koperasi dan UMKM Kota Denpasar tahun 2018-2019 dan $\mathrm{H}_{2}$ yang menyatakan jumlah kredit berpengaruh positif dan signifikan terhadap jumlah sisa hasil usaha diterima.

c) Pengaruh Jumlah Modal Kerja Terhadap Jumlah Sisa Hasil Usaha

Menurut hasil penelitian yang sudah didapat, menunjukkan bahwa nilai Sig. $=0,017$ ( $\alpha<$ 0,05 ) dan uji t sebesar 2,481, maka disimpulkan bahwa jumlah modal kerja berpengaruh positif signifikan terhadap jumlah sisa hasil usaha pada koperasi simpan pinjam yang bernaung di bawah Dinas Koperasi dan UMKM Kota Denpasar tahun 2018-2019 dan $\mathrm{H}_{3}$ yang menyatakan jumlah modal kerja berpengaruh positif dan signifikan terhadap jumlah sisa hasil usaha diterima.

d) Pengaruh Jumlah Simpanan, Jumlah Kredit, dan Jumlah Modal Kerja Terhadap Jumlah Sisa Hasil Usaha

Menurut hasil penelitian yang sudah didapat, menunjukkan bahwa nilai signifikansi yaitu sebesar 0,000 yang berarti jumlah simpanan, jumlah kredit, dan jumlah modal kerja secara bersama-sama berpengaruh signifikan terhadap jumlah sisa hasil usaha pada koperasi simpan pinjam yang bernaung di bawah Dinas Koperasi dan UMKM Kota Denpasar tahun 2018-2019. $\mathrm{H}_{4}$ yang menyatakan jumlah simpanan, jumlah kredit, dan jumlah modal kerja berpengaruh dan signifikan terhadap jumlah sisa hasil usaha diterima.

\section{CONCLUSION}

Hasil penelitian menunjukkan bahwa jumlah simpanan memiliki pengaruh yang negatif dan signifikan terhadap jumlah sisa hasil usaha, jumlah kredit berpengaruh positif dan signifikan terhadap jumlah sisa hasil usaha, jumlah modal kerja berpengaruh positif dan signifikan terhadap jumlah sisa hasil usaha serta jumlah simpanan, jumlah kredit, dan jumlah modal kerja berpengaruh signifikan terhadap jumlah sisa hasil usaha. Hal ini memiliki arti bahwa jumlah simpanan, jumlah kredit, dan jumlah modal kerja memberikan dampak yang baik sehingga pengelolaan usaha koperasi baik dengan pencapaian SHU yang baik pula.

Suggestion

Menurut hasil penelitian di atas, koperasi lebih giat menghimbau para anggota untuk meningkatkan perolehan jumlah simpanan, lebih meningkatkan jumlah kredit dengan cara 
memperkecil bunga dan administrasi yang diharapkan dapat menarik anggota untuk meningkatkan partisipasinya dalam pinjaman modal kepada koperasi, serta lebih memperbesar jumlah modal kerja untuk meningkatkan Sisa Hasil Usaha (SHU).

Acknowledgments

Peneliti tentunya mengucapkan terimakasih kepada Tuhan yang sudah membantu peneliti dalam menyelesaikan jurnal ini, juga kepada keluarga, teman-teman dan semuanya yang telah membantu dalam pembuatan penelitian ini.

\section{REFERENCES}

Rudianto, 2010, Akuntansi Koperasi, Edisi Kedua, Penerbit Erlangga, Jakarta

Hendrojogi, 2015, Koperasi: Asas-Asas, Teori, dan Praktik, Penerbit PT Raja Grafindo Persada, Jakarta

Agnes Sawir, 2005, Pengertian Modal Kerja, Penerbit PT Gramedia Pustaka Utama

Horne, James C. dan John M. W. Jr, 2005, Fundamentals of Financia Management (PrinsipPrinsip Manajemen Keuangan), Penerbit Salemba Empat, Jakarta

Amin Tunggal Wijaya, 2002, .Akuntansi untuk Koperasi,Penerbit Harvarindo, Yogakarta Muhammad Razali, Tumpal Manik, Iranita, 2017, Pengaruh Jumlah Anggota, Jumlah Simpanan, Jumlah Modal Kerja Dan Volume Usaha Terhadap Perolehan Sisa Hasil Usaha Pada Koperasi Se- Kota Tanjungpinang, http://jurnal.umrah.ac.id/?p=7936 Diakses pada 30 Agustus 2020

Firas Septian, Anjuman Zukhri, Made Ary Meitriana, 2014, Pengaruh Jumlah Kredit Dan Jumlah Simpanan Terhadap Rentabilitas Pada Kpri Balidita Gondol Periode 20082012, https://ejournal.undiksha.ac.id/index.php/JJPE/article/view/2025 Diakses pada 30 Agustus 2020 